\title{
PERBEDAAN HOUSE INDEX (HI) SEBELUM DAN SESUDAH PENANGGULANGAN FOKUS DI KELURAHAN TAWANGANOM KECAMATAN MAGETAN KABUPATEN MAGETAN TAHUN 2018 \\ Fitria Rizki Ramadhani, Koerniasari, Sri Mardoyo
}

\section{ABSTRAK}

Demam Berdarah Dengue (DBD) merupakan penyakit yang jumlah penderitanya semakin meningkat setiap tahun dan penyebarannya semakin luas. Permasalahan yang dikaji dalam penelitian ini adalah upaya penanggulangan fokus (PF) meliputi Penyuluhan, Pemberantasan Sarang Nyamuk (PSN), Larvasidasi, Fogging. Penelitian bertujuan menganalisis perbedaan House Index (HI) sebelum dan sesudah penanggulangan fokus di Kelurahan Tawanganom Kecamatan Magetan Kabupaten Magetan.

Jenis Penelitian ini menggunakan metode penelitian analitik Ex Post Facto dengan pendekatan cross sectional. Teknik pengumpulan data lebih diutamakan secara observasi. Jumlah sampel 225 rumah atau kepala/anggota keluarga.

Berdasarkan hasil uji T-test sampel berpasangan (paired-sampel $T$ test) menunjukkan bahwa ada perbedaan yang bermakna House Index (HI) demam berdarah dengue antara sebelum dan sesudah penanggulangan fokus dengan $p$ value $(0,000)<\alpha(0,005)$. Kesimpulan dalam penelitian ini adalah penanggulangan fokus dapat meningkatkan Angka Bebas Jentik khususnya House Index (HI) demam berdarah dengue di KPR Asabri I Tawanganom Indah RW.5 Kelurahan Tawanganom Kecamatan Magetan Kabupaten Magetan.

Kata Kunci : House Index, Penanggulangan Fokus DBD.

\section{PENDAHULUAN}

Asia merupakan wilayah yang menempati urutan pertama kasus Demam Berdarah Dengue (DBD) karena memiliki jumlah penderita paling banyak setiap tahunnya. World Health Organization (WHO) juga menyatakan bahwa sejak tahun 1968 sampai dengan tahun 2009, Indonesia merupakan negara yang memiliki kasus DBD tertinggi di Asia Tenggara (Depkes RI, 2010).

Pada tahun 2016 secara nasional jumlah kabupaten/kota yang terjangkit kasus DBD terus mengalami peningkatan, sebanyak 90,08\% kabupaten/kota di Indonesia mengalami kasus DBD dan di Jawa Timur jumlah kasus DBD sebesar 24.005 penderita (CFR: 1,42\%), dengan jumlah kematian sebanyak 340 orang (IR: 61,43 per 100.000 penduduk) (Kemenkes RI, 2017).

Tingginya kasus DBD membuat pelayanan kesehatan memegang peranan penting dalam pengendalian penyakit DBD. Di Kabupaten Magetan pada tahun 2016 terjadi kasus 165 kasus DBD dengan jumlah kematian sebanyak 4 orang dan 
tahun 2017 terjadi kasus sebanyak 124 dengan kematian 3 kasus (Dinkes Kabupaten Magetan, 2017).

Wilayah kerja Puskesmas Candirejo jumlah penderita DBDnya dalam kategori tinggi, khususnya di KPR Asabri I Tawanganom Indah RW.5 Kelurahan Tawanganom Kecamatan Kota Magetan Kabupaten Magetan. Hasil penyelidikan epedemiologi (PE) ditemukan 4 penderita DBD dan ditemukan 5 tersangka DBD serta ditemukan jentik $\geq 5 \%$ dari rumah / bangunan yang diperiksa, sehingga perlu dilakukan penanggulangan fokus berupa penggerakan masyarakat dalam bentuk pemberantasan sarang nyamuk (PSN) DBD, larvasidasi, penyuluhan dan pengasapan (fogging) (Dinkes Kabupaten Magetan, 2017).

Tujuan penelitian untuk mengetahui perbedaan House Index (HI) sebelum dan sesudah penanggulangan fokus di KPR Asabri I Tawanganom Indah RW.5
Kelurahan Tawanganom Kecamatan Magetan Kabupaten Magetan.

\section{METODE PENELITIAN}

Jenis penelitian analitik Ex Post Facto menggunakan variabel bebas atribut yaitu responden (data house index) sudah ada sebelum proses penelitian dilakukan dengan pendekatan cross sectional (Syahrini, E. N., 2010). Populasi penelitian 516 rumah. Sampel penelitian 225 rumah yang berada seputar 100 meter dari rumah penderita dan diambil wakil-wakil dari tiap kelompok yang ada dalam populasi yang jumlahnya disesuaikan dengan jumlah anggota subjek yang ada di dalam masing-masing kelompok (Arikunto, 2005).

\section{HASIL DAN PEMBAHASAN}

Keberadaan Jentik (House Index) Sebelum Penanggulangan Fokus (PF).

Dari hasil penelitian, didapatkan sebagai berikut:

Tabel 1. Persentase House Index (HI) Sebelum Pelaksanaan Penanggulangan Fokus DBD - Tahun 2018

\begin{tabular}{cccccc}
\hline \multirow{2}{*}{ No } & \multirow{2}{*}{ Diperiksa } & \multirow{2}{*}{ Jumlah } & \multicolumn{2}{c}{ Hasil } & HI \\
\cline { 3 - 5 } & & 225 & Positif & Negatif & (\%) \\
\hline 1. & Rumah & 439 & 123 & 332 & \multirow{2}{*}{40,9} \\
\hline 2. & Kontainer & & & & 133 \\
\hline
\end{tabular}


Berdasar tabel 1 dari 225 rumah yang diperiksa 92 rumah positif jentik nyamuk, 439 kontainer yang diperiksa 123 kontainer positif jentik nyamuk dan sisanya 332 kontainer negatif jentik nyamuk. House index (HI) 40,9\% berarti kepadatan jentik dalam kategori kepadatan tinggi. Kepadatan jentik adalah salah satu indikator yang digunakan untuk memantau keberadaan nyamuk $A$. aegypti dalam suatu wilayah. Kepadatan jentik dapat mempengaruhi kepadatan nyamuk Aedes aegypti sebagai vektor dari virus dengue. Pada lokasi penelitian selama penyelidikan epidemiologi (PE) ditemukan 4 penderita, 5 tersangka dan ditemukan jentik $\geq 5 \%$ dari rumah / bangunan yang diperiksa.

\section{Penyuluhan}

Hasil evaluasi pelaksanaan kegiatan penanggulangan fokus (PF) bidang PSN DBD diperoleh nilai sebesar 23, kategori baik. Pelaksanaan kegiatan penyuluhan dilaksanakan sesuai dengan standart operasional prosedur (SOP) penyuluhan.

Kegiatan penyuluhan berjalan lancar dan sasaran (masyarakat) memahami tentang penyuluhan yang diberikan hal ini ditandai dalam proses penyuluhan terjadi interaksi antara penyuluh dan sasaran (masyarakat).

Pelaksanaan penyuluhan ini sudah direncanakan dengan matang dan mampu menganalisa situasi demi kelancaran pelaksanaan penyuluhan.

Pembinaan peran serta masyarakat dalam melaksanakan pencegahan penyakit DBD sangat penting dengan memberikan pengetahuan dan keterampilan tentang teknik-teknik PSN (Sitio A., 2008).

\section{Pemberantasan Sarang Nyamuk} (PSN).

Hasil evaluasi pelaksanaan kegiatan penanggulangan fokus (PF) bidang PSN DBD diperoleh nilai sebesar 23 kategori baik. Pemantauan kegiatan dilakukan masyarakat dalam hal: 1) Mengganti air vas bunga, minuman burung dan tempat-tempat lainnya. 2) Memperbaiki saluran dan talang air yang tidak lancar/rusak. 3) Menutup lubang-lubang pada potongan bambu, pohon dan lain dengan tanah.

Membersihkan/mengeringkan

tempat-tempat yang dapat menampung air seperti pelepah pisang atau tanaman lainnya. 5) Mengeringkan tempat-tempat lain 
yang dapat menampung air hujan di kosong dan lain-lain. 6) Memelihara ikan pemakan jentik nyamuk. 7) Pemasangan kawat kasa. 8) Tidak menggantung pakaian di dalam rumah. 9) Tidur menggunakan kelambu. 10) Mengatur pencahayaan dan ventilasi yang memadai. 11) Penggunaan obat anti nyamuk untuk mencegah gigitan nyamuk.

\section{Larvasidasi}

Hasil evaluasi pelaksanaan kegiatan penanggulangan fokus (PF) bidang larvasidasi DBD diperoleh nilai sebesar 13, kategori baik. Pelaksanaan larvasidasi dilakukan dengan membubuhkan larvasida temephos di tempat-tempat yang sulit dikuras. Pada saat pelaksanaan larvasidasi, jika jentik tidak tampak karena warna air terlalu dalam dan gelap dilakukan larvasidasi dengan pemberian larvasida dengan dosis tiap 10 gram untuk 100 liter air.

\section{Fogging}

Hasil evaluasi pelaksanaan

kegiatan penanggulangan fokus bidang pekarangan, kebun, rumah-rumah pengasapan (fogging / ULV) DBD nilai sebesar 46 kategori baik. Fogging berguna untuk memutus rantai resiko penularan DBD yang ditularkan oleh nyamuk Aedes aegypti. Fogging fokus dilaksanakan 2 siklus beradius 200 meter dalam selang waktu 1 minggu,

Pelaksanaan intervensi (perlakuan) penanggulangan fokus sepenuhnya dilakukan oleh Dinas Kesehatan dan Puskesmas Candirejo.

Hasil evaluasi pelaksanaan kegiatan penanggulangan fokus (PF) kegiatan adalah 1) Pelaksanan kegiatan fogging mendapat dukungan penuh dari seluruh lapisan masyarakat.

2) Pelaksanaan fogging dilaksanakan pada pukul 08.00-10.00 WIB dan sore hari pada pukul 15.00-17.00 WIB. 3) Keterbukaan masyarakat dalam menerima petugas fogging dalam melaksanakan kegiatan fogging yang dilakukan di dalam rumah. 4) Masyarakat tidak takut fogging membunuh penghuni rumah atau hewan peliharaan. 5) Mesin fogging dalam kondisi baik. 6) Nilai House

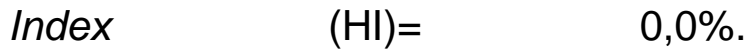

Tabel 2. Perilaku responden tentang DBD di KPR Asabri I Tawanganom Indah RW.5 Kel. Tawanganom - tahun 2018

\begin{tabular}{|c|c|c|c|}
\hline No & Kategori & Jumlah & Persentase (\%) \\
\hline 1. & Baik & 217 & 96,4 \\
\hline 2. & Cukup & - & - \\
\hline 3. & Kurang & 8 & 3,6 \\
\hline
\end{tabular}


$\frac{\text { Jumlah }}{\text { Tabel } 2 \text { diketahui bahwa perilaku }}$ responden terbanyak dalam kategori baik $217(96,4 \%)$ dan 8 responden $(3,6 \%)$ dengan kategori kurang.

Benyamin

Bloom

menyebutkan bahwa perilaku merupakan gabungan dari tiga domain yaitu pengetahuan, sikap dan tindakan sebagaimana pendapat dari Skinner bahwa perilaku merupakan respon atau reaksi seseorang terhadap stimulus atau rangsangan dari luar. (Soekidjo Notoatmodjo, 2003).

Perilaku manusia hakikatnya adalah suatu aktivitas manusia itu sendiri,
225 100

sehingga perilaku yang baik dapat membawa diri ke arah yang baik pula, baik dari segi kesehatan, sosialbudaya maupun yang lainnya (Soekidjo Notoatmodjo, 2003). Maknanya bahwa dengan semangatnya seluruh lapisan masyarakat mendukung penuh pelaksanaan penanggulangan fokus karena masyarakat sudah didasari perilaku (pengetahuan, sikap dan tindakan) yang baik.

\section{Evaluasi Penanggulangan Fokus} (PF).

Tabel 3. Evaluasi Penanggulangan Fokus Penyakit DBD di KPR Asabri I Tawanganom Indah RW.5 Kel. Tawanganom - tahun 2018

\begin{tabular}{clccc}
\hline No & $\begin{array}{c}\text { Variabel } \\
\text { Pengendalian Fokus }\end{array}$ & $\begin{array}{c}\text { Jumlah } \\
\text { Pernyataan }\end{array}$ & Ya & Tidak \\
\hline 1 & PSN & 24 & 23 & 1 \\
\hline 2 & Larvasidasi & 13 & 13 & 0 \\
\hline 3 & Penyuluhan & 15 & 12 & 3 \\
\hline 4 & Pengasapan (Fogging / ULV) & 48 & 46 & 2 \\
\hline Jumlah & 100 & 94 & 6 \\
\hline
\end{tabular}

Hasil evaluasi pelaksanaan kegiatan penanggulangan fokus DBD diperoleh nilai sebesar 94 dinyatakan dalam kategori baik.
Keberadaan Jentik (House Index) Sesudah Penanggulangan Fokus (PF)

Tabel 4. Persentase House Index Sesudah Pelaksanaan Penanggulangan Fokus DBD di KPR Asabri I Tawanganom Indah RW.5 Kel. Tawanganom tahun 2018

\begin{tabular}{cccccc}
\hline \multirow{2}{*}{ No } & \multirow{2}{*}{ Diperiksa } & \multirow{2}{*}{ Jumlah } & \multicolumn{2}{c}{ Hasil } & HI \\
\cline { 4 - 5 } & & Positif & Negatif & $(\%)$ \\
\hline 1. & Rumah & 225 & 0 & 225 & \multirow{2}{*}{0,0} \\
\hline 2. & Kontainer & 439 & 0 & 439 & \\
\hline
\end{tabular}


Tabel 4 menunjukkan House Index (HI) DBD setelah kegiatan penanggulangan fokus kategori risiko penularan rendah, angka House Index setelah kegiatan Pengendalian Fokus sebesar 0\%. Pelaksanaan kegiatan pengendalian fokus terutama PSN merupakan kegiatan yang paling berpengaruh terhadap keberadaan jentik nyamuk di tempat penampungan air. Seseorang melakukan praktek PSN DBD berarti telah melaksanakan praktek pencegahan (preventif) yang merupakan aspek dari perilaku pemeliharaan kesehatan (health maintenance) dan pelaksanaan perilaku kesehatan lingkungan (Soekidjo Notoatmodjo, 2003).

$$
\text { Pemberdayaan masyarakat }
$$
melalui penggerakan jumantik merupakan salah satu cara yang efektif dalam upaya pencegahan penyakit DBD. Model penyadaran masyarakat dapat lebih efektif jika dilakukan oleh kader kesehatan atau tokoh masyarakat karena tokoh panutan ini terlibat langsung dalam kegiatan kemasyarakatan dan lebih dekat dengan masyarakat (Yuli Kusumawati dan S. Darnoto, 2008).

Pemeriksaan jentik oleh petugas berupa kunjungan yang berulang-ulang disertai penyuluhan diharapkan agar masyarakat dapat melakukan PSN DBD secara teratur dan terus-menerus (Depkes RI, 2010).

\section{KESIMPULAN}

House Index (HI) sebelum pelaksanaan penanggulangan fokus $40,9 \%$ dan sesudah pelaksanaan penanggulangan fokus $0 \%$. Ada perbedaan keberadaan jentik house index (HI) antara sebelum dan sesudah penanggulangan fokus (PF). Penanggulangan Fokus efektif dapat meningkatkan Angka Bebas Jentik DBD (House Index) dengan nilai $p$ $(0,000)$.

\section{SARAN}

Pelaksanaan fogging dilakukan 2 (dua) siklus sesuai dengan standart operasional prosedur (SOP). Menjalin kerjasama dengan sektor pendidikan dimulai dari Sekolah Dasar sampai dengan Perguruan Tinggi dalam upaya pemberantasan jentik. Kinerja jumantik ditingkatkaan secara berkala dengan pemberian pelatihan. Memaksimalkan peran seksi promosi kesehatan melalui penggunaan media cetak maupun media elektronik. Melakukan kegiatan PSN 
DBD secara rutin minimal seminggu sekali dengan pola $4 \mathrm{M}$ Plus

\section{DAFTAR PUSTAKA}

Arikunto, S., 2005. Manajemen Penelitian. Jakarta: Rineka Cipta.

Depkes RI, 2010. Buletin Jendela Epidemiologi, Vol. 2, Agustus. Jakarta: Pusat Data dan Surveilans Epidemiologi Kemenkes RI.

Dinkes Kabupaten Magetan, 2017. Laporan Kasus DBD.

Kementerian Kesehatan RI, 2017.

Data dan Informasi Profil Kesehatan Indonesia 2016. Jakarta: Kemenkes RI.

Kusumawati, Yuli dan S. Darnoto, 2008, Pelatihan Peningkatan Kemampuan Kader Posyandu dalam Penanggulangan Demam Berdarah Dengue (DBD) di Kelurahan Joyotakan Kecamatan Serengan

Surakarta, Warta, Vol. 11, No. 2, September 2008.

Notoatmodjo, Soekidjo. 2003. IImu Kesehatan Masyarakat PrinsipPinsip Dasar. Jakarta: Rineka Cipta.

Sitio, A., 2008. Hubungan Perilaku Tentang Pem- berantasan Sarang Nyamuk dan Kebiasaan
(Menguras, Mengubur, Menutup, Memantau).

Keluarga dengan Kejadian Demam Berdarah Dengue di Kecamatan Medan Perjuangan Kota Medan [Tesis]. Semarang: Universitas Diponegoro.

Syahrini, E. N., 2010. Desain Penelitian. Semarang: Fakultas Kesehatan Masyarakat Universitas Diponegoro (UNDIP).

Surat Edaran Kemenkes Nomor PM.01.11/Menkes/591/2016 tanggal 8 November 2016 tentang gerakan 1 rumah 1 jumantik. 